\title{
ANALISIS RISIKO PRODUKSI USAHATANI PADI LAHAN BASAH DAN LAHAN KERING DI KABUPATEN MELAWI
}

\author{
ROFINUS RAMA ${ }^{1)}$, NURLIZA ${ }^{2)}$, EVA DOLOROSA ${ }^{2)}$ \\ 1) Alumni Magister Manajemen Agribisnis Fakultas Pertanian Universitas \\ Tanjungpura Pontianak. \\ 2) Staf Pengajar Fakultas Pertanian Universitas Tanjungpura Pontianak
}

\begin{abstract}
This study aims to analyze the production risk of rice farm and compare production risk betwen wetland rice farm and field rice farm. The method used in this study is deskriptive and quantitative method. The location is determined by purposive. Data obtained through interviews with160 randomly simple rice farmers. The method used is just and pope production of multiple linear regression analysis with cobb douglas method and test analysis.

The results of this research were: the model showed that the factors such as land width, seeds, urea fertilizers, pesticides and quantity of family labours had a real influence to the increase of the wetland rice farm production. While NPK fertilizers, age and education of farmers did not influence to (non-significant) the increasing of rice production. The model used in this research had showed that land width, pesticides, quantity of family labours and age of farmers had a real influence to the increase of the field rice farm production. While seeds and education farmer did not influence to (non-significant) the increasing of rice production. Compare production risk between wetland rice farm and field rice farm showed real difference.
\end{abstract}

Keywords: Risk, Production, Rice Farm, wetland and field.

\section{PENDAHULUAN}

Kabupaten Melawi merupakan salah satu kabupaten di bagian timur Kalimantan Barat yang cukup potensial untuk pengembangan tanaman pertanian terutama padi yang merupakan sumber pangan terbesar di kabupaten tersebut. Produksi total padi tahun 2015 di kabupaten Melawi secara keseluruhan sebesar 36.246 ton, dari jumlah tersebut tersebar di 11 kecamatan dengan luas panen seluas 16.632 hektar sedangkan produktifitas padi sebesar 23,6 kuintal per hektarnya. Sementara itu pemanfaatan lahan untuk pertanian di Kabupaten Melawi cenderung meningkat setiap tahunnya.

Usahatani padi didukung penuh oleh pemerintah melalui dana daerah maupun bantuan sosial pusat yang digulirkan setiap tahunnya. Berbagai program ekstensifikasi, intensifikasi maupun program upaya khusus yang digalakkan oleh Pemerintahan sekarang guna meningkatkan Ketahanan Pangan Daerah maupun Nasional.Namun demikian bansos yang diberikan belum memberikan pengaruh yang nyata terhadap peningkatan produksi padi karena masih belum mencukupi jika dibandingkan luas wilayah dan jumlah desa yang memiliki potensi.

Usahatani padi di kabupaten Melawi tidak dapat dipisahkan dari resiko yang berdampak pada produksi. Sumber risiko dari internal merupakan risiko produksi dan teknik yaitu risiko produksi yang terjadi oleh adanya hubungan teknis antara output dan tingkat penggunaan input. Menurut Asche dan Tveteras (1999), faktor 
produksi atau input produksi dapat bersifat meningkatkan risiko dan ada pula yang mengurangi risiko. Penggunaan faktor produksi dapat menjadi penyebab sebagai pengurang risiko produksi(Risk Reducing Factor) atau sebagai penyebab meningkatnya risiko produksi(Risk Inducing Factor). Penggunaan input pupuk masih belum sesuai anjuran rekomendasi karena keterbatasan jumlah dan keterlambatan waktu penggunaan pupuk oleh petani. Kurangnya alat mesin pertanian dan penguasaannya dirasa masih kurang oleh petani misalnya penggunaan hand traktor. Insfrastruktur jaringan irigasi dan jalan usahatani walaupun sudah banyak yang dibangun dirasa masih kurang memadai. Serangan hama dan penyakit ini juga sangat berpengaruh terhadap resiko produksi padi apalagi petani kurang memahami risiko yang diakibatkan oleh serangan hama dan penyakit.

Usahatani pada lahan basah dihadapkan pada permasalahan yaitu reaksi tanah yang masam( $\mathrm{pH}$ rendah), adanya pirit, serta pelandaian produktifitas(levelling off) dalam produksi padi yang disebabkan oleh banyak faktor, diantaranya iklim, topografi, dan degradasi kesuburan tanah. Pemanfaatan lahan kering untuk usahatani padi dihadapkan masalah keterbatasan sumber air karena sumber pengairannya berasal dari air hujan. Masalah lain dihadapi pada usahatani lahan kering adalah tingkat kesuburan yang rendah, tanah bereaksi masam ( $\mathrm{pH}$ rendah), bahan organik rendah, kadar $\mathrm{Al}$ yang tinggi, dan solum(ketebalan) tanah yang rendah dan lahan kering banyak dijumpai pada daerah yang miring sehingga mudah terdegradasi oleh erosi tanah. Faktor input produksi bukan merupakan satu-satunya yang menyebabkan risiko produksi padi. Faktor lingkungan atau eksternal merupakan faktor lainnya yang dapat menyebabkan risiko. Beberapa faktor eksternal yang dapat menyebabkan risiko produksi padi adalah perubahan iklim, curah hujan, kekeringan dan hama penyakit.

Adapun tujuan penelitian ini adalah (a) Menganalisa faktor-faktor yang mempengaruhi produksi usaha tani padi pada lahan basah dan lahan kering (b) Menganalisa faktor-faktor yang mempengaruhi risiko produksi usaha tani padi pada lahan basah dan lahan kering (c) Menganalisa perbandingan risiko produksi usaha tani lahan basah dan lahan kering.

\section{METODE PENELITIAN}

Dalam penelitian ini menggunakan metode penelitian yang dilakukan dengan pendekatan Observasi, Survey dan Kepustakaan. Teknik pengambilan Lokasi penelitian dipilih secara sengaja (purposive sampling). Menurut Sugiyono (2009) purposive sampling adalah teknik penentuan sampel dengan pertimbangan tertentu. Penelitian dilaksanakan di Kabupaten Melawi difokuskan pada dua kecamatan yang memiliki potensi pertanian padi lahan basah dan lahan kering yaitu Kecamatan Belimbing dan Kecamatan Ella Hilir. Waktu penelitian kurang lebih dua bulan dengan menggunakan metode deskriftif dan kuantitatif. Data dikumpulkan dengan melakukan wawancara yang disertai dengan daftar kuisioner terstruktur.

Untuk pengambilan sample petani dalam penelitian ini dilakukan secara simple random sampling. Menurut Sugiyono (2009), simple random sampling merupakan prosedur pengambilan sampel dari populasi dilakukan secara acak tanpa memperhatikan strata yang ada dalam populasi. Petani responden yang 
diambil adalah petani yang melakukan usahatani padi sebanyak 160 orang dimana 80 orang petani padi di lahan basah di Kecamatan Belimbing dan 80 orang petani di lahan kering di Kecamatan Ella Hilir.

\section{Metode Analisis Data}

\section{Analisis Model Fungsi Risiko Produksi Just dan Pope}

Analisis regresi fungsi risiko produksi Just dan Pope digunakan untuk menjawab hipotesis penelitian satu dan penelitian dua sekaligus yaitu :

1. Hipotesis satu adalah diduga produksi usahatani padi pada lahan basah dan lahan kering dipengaruhi oleh penggunaan luas lahan, benih, urea, NPK Phonska, herbisida, jumlah tenaga kerja keluarga, umur petani dan pendidikan.

2. Hipotesis dua adalah diduga risiko produksi usahatani padi pada lahan basah dan lahan kering dipengaruhi oleh penggunaan luas lahan, benih, urea, NPK Phonska, herbisida, jumlah tenaga kerja keluarga, umur petani dan pendidikan.

Fungsi produksi yang digunakan dalam model Just dan Pope adalah fungsi produksi tipe Cobb-Douglas yang kemudian diubah dalam bentuk logaritma natural. Sehingga model fungsi produksi Just dan Pope secara matematis dapat dituliskan sebagai berikut :

Fungsi produksi $\mathrm{Y}=\mathrm{f}(\mathrm{X})$

$$
\text { (3. 1) }
$$

Ln Y $=\ln \beta_{0}+\beta_{1} \ln \operatorname{lhn}+\beta_{2} \ln$ bnh $+\beta_{3} \ln$ urea $+\beta_{4} \ln n p k+\beta_{5}$

$\ln$ herb $+\beta_{6} \ln \mathrm{tkk}+\beta_{7} \ln \mathrm{umr}+\beta_{8} \ln \mathrm{pddk}+\varepsilon$

Variance produksi $\sigma^{2}=\mathrm{f}(\mathrm{X})$

$\operatorname{Ln} \sigma^{2} \mathrm{Y}$ (3. 2)

$+\theta_{5} \ln$ herb $+\theta_{6} \ln$ tkk $+\theta_{7} \ln \mathrm{umr}+\theta_{8} \ln$ pddk $+\varepsilon$

Keterangan :

$$
\begin{aligned}
& \text { Ln Y = produksi padi }(\mathrm{kg} / \mathrm{ha} / \text { musim }) \\
& \text { Ln } \sigma^{2} \quad=\text { variance produksi padi (risiko produksi) } \\
& \beta_{0} / \theta_{0} \quad=\text { Intersept } \\
& \beta / \theta \quad=\text { koefisien regresi (parameter yang ditaksir) }(i=1 \mathrm{~s} / \mathrm{d} 8) \\
& \varepsilon=\text { error term/disturbance error/pengganggu } \\
& \text { LHN = lahan (ha) } \\
& \text { BNH = benih }(\mathrm{kg} / \mathrm{ha} / \mathrm{musim}) \\
& \text { UREA = Urea }(\mathrm{kg} / \mathrm{ha} / \mathrm{musim}) \\
& \text { NPK Ponska }=\text { NPK Ponska }(\mathrm{kg} / \mathrm{ha} / \mathrm{musim}) \\
& \text { HERB = herb (liter/ha/musim) } \\
& \text { TKK = tenaga kerja keluarga (org/ha/musim) } \\
& \text { UMR = umur petani (tahun) } \\
& \text { PDDK = pendidikan (tahun) }
\end{aligned}
$$

Pada penelitian ini menggunakan alat analisis risiko produksi dengan model Generalized Autoregressive Conditional Heterocedasticity atau GARCH yang sudah mengakomodasi pendugaan secara sekaligus untuk fungsi produksi (mean production function) dan variance (variance production function).

Untuk memperoleh validitas hasil pengujian ekonometrik sesuai Model Ordinary Least Square (OLS), dilakukan pendeteksian penyimpangan dari asumsi-asumsi klasik dan terhadap kesesuaian model (Gujarati, 2006). Pengujian pada penyimpangan asumsi klasik digunakan untuk mendapatkan model terbaik 
untuk melakukan pendugaan. Pengujian dilakukan untuk kedua model fungsi produksi sekaligus fungsi variance.

Untuk mendapatkan model yang tidak bias linier dan merupakan penaksir terbaik (Best Linear Unbiased Estimator : BLUE) dalam penelitian, maka model harus bebas uji asumsi klasik yaitu multikolinearitas, heteroskedastisitas normalitas dan autokorelasi. Kemudian dilakukan uji statistik meliputi uji ketepatan model (Uji F) uji ketepatan parameter penduga (Uji T).

\section{Metode Analisis Tujuan Penelitian tiga}

Hipotesis tiga adalah diduga dalam penelitian ada perbedaan risiko produksi usahatani antara lahan basah dan lahan kering.

Analisis risiko produksi diukur dengan besarnya variance dan standar deviasi.

Rumus variance dan Standar Deviasi adalah sebagai berikut :

$$
\sigma^{2}=\frac{\sum(\mathrm{Xi}-\overline{\mathrm{X}})^{2}}{\mathrm{n}-1}=\sigma=\sqrt{\frac{\sum(\mathrm{Xi}-\overline{\mathrm{X}})^{2}}{\mathrm{n}-1}}
$$

Keterangan :

$\mathrm{X} \quad=$ rata-rata produksi usahatani padi

$\mathrm{Xi} \quad=$ produksi dari sampel usahatani padi

$\sigma^{2} \quad=$ variance dari sampel usahatani padi

$\sigma=$ Standar deviasi

$\mathrm{n}=$ jumlah sampel usahatani padi

Setelah nilai variance diketahui maka dilakukan uji beda antara lahan basah dan lahan kering tersebut dengan menggunakan pengujian komparasi dengan uji $\mathrm{t}($ t.test). Menurut Sugiyono (2009) uji t digunakan untuk menguji hipotesis komparatif dua sampel yang independen. Untuk menentukan rumus uji t yang mana akan digunakan untuk pengujian hipotesis, maka perlu di uji dulu variance kedua sampel apakah homogen atau tidak. Pengujian homogenitas variance digunakan dengan uji $\mathrm{F}$ dengan rumus sebagai berikut :

$$
\mathrm{F}=\frac{\text { Variance terbesar }}{\text { Variance terkecil }}
$$

Hipotesisnya adalah jika nilai $F$ hitung lebih kecil dari $F$ tabel maka variance Homogen $\left(\sigma^{2}=\sigma^{2}\right)$ dan nilai jika $F$ hitung lebih besar dari $F$ tabel maka variance heterogen $\left(\sigma^{2} \neq \sigma^{2}\right)$.

Ada dua model rumus uji t yang digunakan untuk menguji hipotesis komparatif yaitu rumus separated varians dan polled varians. Pemilihan kedua rumus tersebut sesuai dengan ketentuan sebagai berikut :

a. Jika jumlah sampel $\mathrm{n}_{1}=\mathrm{n}_{2}$ dan variance $\sigma 1=\sigma_{2}$ maka dapat menggunakan rumus t-tes 1 dan 2, untuk mengetahui t- tabel digunakan derajat kebebasan yang besarnya $\mathrm{dk}=\mathrm{n}_{1}+\mathrm{n}_{2}-2$

b. Jika jumlah sampel $\mathrm{n}_{1} \neq \mathrm{n}_{2}$ dan variance $\sigma_{1}=\sigma_{2}$ maka dapat menggunakan rumus t-test 2 , untuk mengetahui t- tabel digunakan derajat kebebasan yang besarnya $\mathrm{dk}=\mathrm{n}_{1}-\mathrm{n}_{2}$

c. Jika jumlah sampel $n_{1}=n_{2}$ dan variance $\sigma_{1} \neq \sigma_{2}$ maka dapat menggunakan rumus t-test 1 dan 2 , untuk mengetahui t- tabel digunakan derajat kebebasan yang besarnya $\mathrm{dk}=\mathrm{n}_{1}-1$ atau $\mathrm{n}_{2}-1$

d. Jika jumlah sampel $n_{1} \neq n_{2}$ dan variance $\sigma_{1} \neq \sigma_{2}$ maka dapat menggunakan rumus t-test 1 , nilai $t$ sebagai pengganti nilai $t$ tabel dihitung dari selisih harga $t$ tabel dengan $\mathrm{dk}=\mathrm{n}_{1}-1$ dan $\mathrm{dk}=\mathrm{n}_{2}-1$, dibagi dua dan kemudian ditambah dengan nilai $\mathrm{t}$ terkecil. 
Analisis uji perbandingan resiko produksi lahan basah dan lahan kering didasarkan pada bentuk hipotesis sebagai berikut :

$\mathrm{H}_{0}=$ tidak ada perbedaan resiko produksi usahatani antara lahan basah dan lahan kering.

$\mathrm{H}_{1}=$ resiko produksi usahatani antara lahan basah dan lahan kering berbeda.

Kriteria keputusan yang diambil apabila nilai t hitung lebih kecil dari pada t tabel $(\alpha=0,05)$ maka tidak ada perbedaan produksi usahatani antara lahan basah dan lahan kering akan tetapi apabila nilai t hitung lebih besar dari pada tabel ( $\alpha=$ $0,05)$ berarti terdapat perbedaan resiko produksi usahatani padi di lahan basah dan lahan kering.

\section{HASIL DAN PEMBAHASAN}

\section{A. Faktor-Faktor yang Mempengaruhi Produksi dan Risiko Produksi Padi di Lahan Basah dan Lahan Kering}

Penggunaan jumlah faktor produksi usahatani lahan basah berbeda dengan lahan kering, dimana pada lahan basah menggunakan 8 variabel bebas (independen) yaitu Lahan, Benih, Urea, NPK, Herbisida, Jumlah Tenaga Kerja Keluarga, Umur dan Pendidikan. Sedangkan untuk dilahan kering menggunakan 6 variabel bebas(independen) karena lahan kering tidak menggunakan pupuk urea dan NPK.

\section{Uji Asumsi Klasik}

Untuk memperoleh hasil estimasi yang BLUE (Best Linear Unbiased Estimator) maka harus dilakukan uji asumsi klasik terhadap gejala multikolineraritas, heteroskedastisitas, normalitas dan autokorelasi untuk fungsi produksi sekaligus fungsi variance risiko produksi. Data yang digunakan dalam penelitian ini adalah data Cross-Section (suatu data yang terdiri dari satu atau lebih variabel yang dikumpulkan pada waktu yang sama). Kemudian dilanjutkan dengan uji statistik yaitu uji f (uji ketepatan model) dan uji t (uji parameter penduga).

\section{Multikolinearitas}

Tujuan uji multikolinearitas ini adalah untuk menguji apakah model regresi yang dihasilkan mempunyai korelasi antar variabel independen. Untuk mengetahui adanya gejala multikolinearitas dapat diamati dari nilai Variance Inflation Factor (VIF) pada tabel 1. berikut ini:

Tabel 1. Uji Multikolineritas Faktor-Faktor yang Mempengaruhi Produksi dan Risiko Produksi Padi Lahan Basah dan Lahan Kering di Kabupaten Melawi Tahun 2015.

\begin{tabular}{lcccc}
\hline \multirow{2}{*}{ Variabel } & \multicolumn{2}{c}{$\begin{array}{c}\text { Collinearity Statistics Lahan } \\
\text { basah }\end{array}$} & \multicolumn{2}{c}{$\begin{array}{c}\text { Collinearity Statistics } \\
\text { Lahan kering }\end{array}$} \\
\cline { 2 - 5 } & Tolerance & VIF & Tolerance & VIF \\
\hline Lahan(x1) & 0,115 & 8,728 & 0,145 & 6,886 \\
Benih(X2) & 0,135 & 7,387 & 0,218 & 4,583 \\
Urea(X3) & 0,224 & 4,456 & 0,227 & 4,397 \\
NPK(X4) & 0,348 & 2,877 & - & - \\
Herbisida(X5) & 0,149 & 6,705 & - & - \\
Tenaga Kerja(X6) & 0,412 & 2,425 & 0,217 & 4,604 \\
Umur(X7) & 0,649 & 1,540 & 0,732 & 1,366 \\
Pendidikan(X8) & 0,680 & 1,470 & 0,750 & 1,333 \\
\hline Sund:
\end{tabular}

Sumber: Analisis data, 2015. 
Menurut Ghozali (2005) bilamana terjadi multikolinearitas jika mempunyai nilai VIF lebih dari 10 dan tolerance dibawah 0,1 dan jika nilai VIF kurang dari 10 dan tolerance diatas 0,1 maka tidak terjadi multikolinearitas. Dari hasil pengujian multikolinearitas diketahui bahwa pada model fungsi produksi dan variance produksi tidak terjadi adanya gejala multikolinearitas antar variabelvariabel independen yang mempengaruhi produksi padi pada lahan basah dan lahan kering, karena nilai VIF lebih kecil dari 10.

\section{Heterokedastisitas}

Menurut Gunawan (2005) heterokedastisitas bertujuan untuk mengetahui apakah dalam model regresi terdapat variasi residual absolut sama atau tidak untuk semua pengamatan. Model regresi yang memenuhi persyaratan adalah di mana terdapat kesamaan varians dari residual satu pengamatan ke pengamatan yang lain tetap atau disebut homoskedastisitas.

Tabel 2. Uji Heterokedastisitas Metode Glejser Test Faktor-Faktor yang Mempengaruhi Produksi dan Risiko Produksi Padi Lahan Basah dan Lahan Kering di Kabupaten Melawi Tahun 2015.

\begin{tabular}{lcc}
\hline \multicolumn{1}{c}{ Variabel } & Lahan basah & Lahan kering \\
& Sign t parsial & Sign t parsial \\
\hline Luas Lahan & 0,023 & $\mathbf{0 , 7 9 5} * *$ \\
Benih & $\mathbf{0 , 1 1 3} * *$ & $\mathbf{0 , 3 9 6 * *}$ \\
UREA & $\mathbf{0 , 6 9 2} * *$ & - \\
NPK & $\mathbf{0 , 8 4 6 * *}$ & - \\
Herbisida & $\mathbf{0 , 6 3 8} * *$ & $\mathbf{0 , 3 2 6}^{* *}$ \\
TenagaKerjaKeluarga & $\mathbf{0 , 8 6 2} * *$ & $\mathbf{0 , 8 2 7} * *$ \\
Umur & $\mathbf{0 , 5 6 3 * *}$ & $\mathbf{0 , 6 5 8} * *$ \\
Pendidikan & $\mathbf{0 , 8 3 3} * *$ & $\mathbf{0 , 3 9 8 * *}$ \\
\hline$* *$ signifikan $\alpha=0,05$ & &
\end{tabular}

Sumber : Analisis Data, 2015.

Dikatakan tidak ada gejala heteroskedastisitas, apabila nilai sign. $\mathrm{t}$ parsial masing-masing variabel lebih besar dari sign $\alpha 0,05$. Dari hasil pengujian heterokedastisitas tersebut diketahui bahwa pada model fungsi produksi dan variance resiko produksi pada lahan basah dan lahan kering tidak terjadi adanya gejala heterokedastisitas karena sebagian besar nilai Sign. t parsial masingmasing variabel lebih besar dari sign. $\alpha 0,05$ sehingga model fungsi tersebut bebas gejala heteroskedastisitas.

\section{Normalitas}

Uji normalitas dilakukan untuk menguji apakah dalam suatu model regresi, variabel dependen, variabel independen atau keduanya mempunyai distribusi normal atau tidak. Pengujian normalitas distribusi data populasi dilakukan dengan menggunakan alat uji statistik Kolmogorov-Smirnov (K-S). 
Tabel 3. Uji Normalitas Kolmogorov-Smirnov(K-S) Faktor-Faktor yang Mempengaruhi Produksi dan Risiko Produksi Padi Lahan Basah dan Lahan Kering di Kabupaten Melawi Tahun 2015.

\begin{tabular}{lcccccc}
\hline & \multicolumn{3}{c}{ Tests of Normality } & & & \\
\hline \multicolumn{1}{c}{ Uraian } & \multicolumn{2}{c}{ Kolmogorov-Smirnov } & \multicolumn{3}{c}{ Shapiro-Wilk } \\
\cline { 2 - 7 } & Statistik & $\mathrm{df}$ & Sign. & Statistik & $\mathrm{df}$ & Sign. \\
\hline $\begin{array}{l}\text { Unstandardized } \\
\text { Residual(Lahan basah) }\end{array}$ & 0,074 & 80 & $\mathbf{0 , 2 0 0 *}$ & 0,987 & 80 & $\mathbf{0 , 5 9 5 *}$ \\
\hline $\begin{array}{l}\text { Unstandardized } \\
\text { Residual(Lahan kering) }\end{array}$ & 0,077 & 80 & $\mathbf{0 , 2 0 0 *}$ & 0,975 & 80 & $\mathbf{0 , 1 2 2 *}$ \\
\hline $\begin{array}{l}\text { *. This is a lower bound of the true significance. } \\
\text { a. Lilliefors Significance Correction }\end{array}$ & & & & & \\
\hline
\end{tabular}

Sumber : Analisis Data, 2015.

Berdasarkan pengujian statistik Kolmogorov-Smirnov pada lahan basah nilai asymp sign. atau nilai probabilitas uji Kolmogorov-Smirnov sebesar 0,20 dan sign. shapiro wilk 0,59 di mana lebih besar dari 0,05 maka data tersebut berdistribusi normal. Sedangkan untuk pengujian statistik lahan kering adalah dengan nilai asymp sign. atau nilai probabilitas uji Kolmogorov-Smirnov sebesar 0,20 dan sign. shapiro wilk 0,12 di mana lebih besar dari 0,05 maka data tersebut berdistribusi normal.

Autokorelasi

Tujuan autokorelasi adalah untuk mengetahui apakah terjadi korelasi diantara data pengamatan atau tidak. Pengujian autokorelasi dalam penelitian ini menggunakan uji Durbin - Watson.

Tabel 4. Uji Autokorelas Faktor-Faktor yang Menpengaruhi Produksi dan Risiko Produksi Usahatani Padi Lahan Basah dan Lahan Kering di Kabupaten Melawi Tahun 2015.

\begin{tabular}{lcc}
\hline Uji Autokorelasi & Lahan basah & Lahan kering \\
\hline Nilai Durbin-Watson & 2,115 & 2,009 \\
\hline
\end{tabular}

Sumber : Analisis Data, 2015.

Cara menentukan pengujian autokorelasi pada usahatani padi lahan basah dan lahan kering adalah dengan nilai Durbin-Watson (DW), yaitu deteksi Autokorelasi Positif. Nilai Durbin-Watson (DW) pada usahatani lahan basah sebesar 2,11 dimana lebih besar dari nilai DU : 1,86. Sedangkan nilai DurbinWatson (DW) sebesar pada lahan kering 2,009 dimana lebih besar dari nilai DU: 1,80 maka dapat disimpulkan tidak terjadi korelasi diantara data pengamatan atau tidak terdapat terdapat autokorelasi.

\section{Analisis Faktor-Faktor yang Mempengaruhi Produksi Usahatani Padi Lahan Basah dan Lahan Kering}

Nilai koefisien determinan $\left(\mathrm{R}^{2}\right)$ pada lahan basah adalah sebesar 0,96 maka kondisi ini menunjukkan bahwa kemampuan variabel independen secara bersamasama dapat menjelaskan variansi variabel dependen sebesar 96,04 persen. Sedangkan sisanya sebesar 3,96 persen dipengaruhi oleh variabel-variabel lain di luar model. Nilai koefisien determinan $\left(\mathrm{R}^{2}\right)$ pada lahan kering adalah sebesar 0,95 maka kondisi ini menunjukkan bahwa kemampuan variabel independen secara bersama-sama dapat menjelaskan variasi variabel dependen sebesar 95,79 persen. 
Sedangkan sisanya sebesar 4,21 persen dipengaruhi oleh variabel-variabel lain di luar model.

Hasil statistik uji $\mathrm{F}$ pada usahatani lahan basah menunjukkan bahwa sign. nilai probabilitas (F statistik $=219,79)$ sebesar 0,00 yang lebih kecil dari sign $\alpha$ 0,05. Sedangkan hasil statistik uji $\mathrm{F}$ pada pada usahatani lahan kering juga menunjukkan bahwa sign. nilai probabilitas $(\mathrm{F}$ statistik $=281,58)$ sebesar 0,00 yang lebih kecil dari sign $\alpha 0,05$. Maka artinya semua faktor produksi (variabel independen) yang digunakan dalam usahatani padi lahan basah dan lahan kering secara bersama-sama berpengaruh nyata terhadap produksi dan variance (resiko produksi) padi pada taraf nyata lima persen.

Tabel 5. Hasil Estimasi Fungsi Produksi Usahatani Padi Lahan Basah dan Lahan Kering dengan Model GARCH di Kabupaten Melawi Tahun 2015.

\begin{tabular}{|c|c|c|}
\hline \multirow[t]{2}{*}{ Variabel } & Lahan basah & Lahan kering \\
\hline & $\begin{array}{l}\text { Koefisien } \\
\text { estimasi }\end{array}$ & $\begin{array}{l}\text { Koefisien } \\
\text { estimasi }\end{array}$ \\
\hline (Constant) & $\begin{array}{l}-6,341 \\
(-2,342)\end{array}$ & $\begin{array}{l}1,281 \\
(0,672)\end{array}$ \\
\hline Luas Lahan & $\begin{array}{l}\mathbf{9 , 6 6 6 * * *} \\
(4,222)\end{array}$ & $\begin{array}{l}\mathbf{1 2 , 4 0 2 * * * *} \\
(10,662)\end{array}$ \\
\hline Benih & $\begin{array}{l}\mathbf{0 , 3 2 6 * * * *} \\
(2,689)\end{array}$ & $\begin{array}{l}-0,066 \\
(-1,423)\end{array}$ \\
\hline UREA & $\begin{array}{l}\mathbf{0 , 0 6 0 * * * *} \\
(3,017)\end{array}$ & $\begin{array}{l}- \\
-\end{array}$ \\
\hline NPK & $\begin{array}{l}0,017 \\
(1,607)\end{array}$ & $\begin{array}{l}- \\
-\end{array}$ \\
\hline Herbisida & $\begin{array}{l}\mathbf{0 . 0 0 2} * * * \\
(3,522)\end{array}$ & $\begin{array}{l}\mathbf{0 , 0 0 3} * * * \\
(6,998)\end{array}$ \\
\hline Tenaga Kerja Keluarga & $\begin{array}{l}\mathbf{2 , 3 9 7 * *} \\
(2,476)\end{array}$ & $\begin{array}{l}\mathbf{1 , 1 1 2} * * \\
(2,358)\end{array}$ \\
\hline Umur & $\begin{array}{l}0,044 \\
(0,950)\end{array}$ & $\begin{array}{l}-\mathbf{0 , 0 5 0 *} \\
(-1,895)\end{array}$ \\
\hline Pendidikan & $\begin{array}{l}-0,140 \\
(-0,715)\end{array}$ & $\begin{array}{l}0,110 \\
(1,090)\end{array}$ \\
\hline R-squared & 0,960432 & 0,957904 \\
\hline Adjusted R squared & 0,955974 & 0,954444 \\
\hline F-Statistik & 219,7940 & 281,5830 \\
\hline
\end{tabular}

Sumber : Analisis Data, 2015.

Untuk mengetahui pengaruh masing-masing faktor yang mempengaruhi produksi padi bedasarkan nilai koefisien estimasi dari hasil uji t (individual test) dapat dilihat pada tabel 5 .

Luas lahan pada usahatani lahan basah maupun lahan kering berpengaruh sangat signifikan dan positif terhadap produksi padi lahan basah. Penambahan luas lahan basah sebesar 1 persen akan menambah produksi padi sebesar 9,66 persen sedangkan penambahan luas lahan kering sebesar 1 persen akan menambah produksi padi sebesar 12,40 persen. Produktifitas lahan basah dan lahan kering di Kabupaten Melawi masih cukup baik, dimana koefisien estimasi luas lahan cukup 
besar dan bernilai positif dalam mempengaruhi peningkatan produksi padi jika dilakukan penambahan luas lahan.

Jumlah benih pada usahatani lahan basah berpengaruh sangat signifikan dan positif terhadap produksi padi lahan basah sedangkan pada usahatani lahan kering tidak berpengaruh signifikan terhadap produksi padi lahan kering. Penambahan jumlah benih sebesar 1 persen akan menambah produksi padi lahan basah sebesar 0,32 persen. Penggunaan benih padi lahan basah berpengaruh positif menunjukkan bahwa mutu benih yang digunakan oleh petani relatif baik. Apabila mutu benih padi unggul ditingkatkan maka akan meningkatkan produksi padi.Benih padi lahan kering tidak memberikan pengaruh yang signifikan terhadap produksi padi lahan kering karena umumnya petani lahan kering atau ladang menggunakan benih padi varietas lokal sehingga mutu benih padi belum sepenuhnya diperhatikan oleh petani sendiri.

Pupuk urea berpengaruh sangat signifikan dan positif terhadap produksi padi lahan basah. Penambahan jumlah urea sebesar 1 persen akan menambah produksi padi sebesar 0,060 persen. Rata-rata penggunaan urea di tingkat petani sebesar 102,54 kg/ha. Artinya dosis tersebut masih dibawah dosis optimal rekomendasi padi yaitu 150 - $200 \mathrm{~kg} / \mathrm{ha}$. Peningkatan produksi masih bisa dilakukan jika Penggunaan urea ditambah sesuai dosis anjuran rekomendasi. Sementara pupuk NPK berpengaruh tidak signifikan terhadap produksi padi lahan basah. Rata-rata penggunaan NPK di tingkat petani hanya sebesar 138,67 kg/ha, artinya dosis tersebut masih dibawah dosis optimal pedoman dasar padi lahan basah yaitu 150 - $300 \mathrm{~kg} / \mathrm{ha}$. Penggunaan NPK tidak memberikan pengaruh nyata dikarenakan dosis yang digunakan masih kurang dari dosis anjuran rekomendasi. Petani pada lahan kering atau jarang melakukan pemupukan karena bergantung pada unsur hara dari bahan organik di lapisan atas tanah (top soils).

Jumlah herbisida berpengaruh sangat nyata dan positif terhadap produksi padi lahan basah maupun lahan kering. Dalam penambahan jumlah herbisida sebesar 1 persen akan menambah produksi padi lahan basah sebesar 0,002 persen sedangkan pada lahan kering akan menambah produksi padi sebesar 0,003 persen. Penggunaan herbisida dalam mengendalikan gulma untuk memberikan lingkungan yang bersih pada ruang tumbuh yang sehat pada tanaman padi.

Jumlah tenaga kerja keluarga berpengaruh signifikan terhadap produksi padi lahan basah maupun lahan kering. Penambahan jumlah tenaga kerja keluarga sebesar 1 persen akan menambah produksi padi lahan basah sebesar 2,39 persen demikian juga pada lahan kering dimana penambahan jumlah tenaga kerja keluarga sebesar 1 persen akan menambah produksi padi sebesar 1,11 persen. Penambahan tenaga kerja masih bisa meningkatkan produksi padi, terutama tenaga kerja untuk pemeliharaan tanaman meliputi penyulaman, pemupukan, penyiangan gulma, pengendalian hama dan penyakit serta pengaturan air irigasi yang semuanya menggunakan tenaga kerja manusia.

Dalam penelitian ini umur berpengaruh tidak signifikan terhadap produksi padi lahan basah. Kondisi ini menunjukkan tidak ada perbedaan apabila tingkat umur petani tersebut tinggi ataupun rendah terhadap peningkatan produksi padi lahan basah. Umur petani pada lahan basah rata-rata berumur 38,96 tahun yang dapat dikategorikan pada usia cukup tua, namun masih bersifat produktif karena mempunyai kematangan berpikir, pengetahuan, pengalaman dan kemampuan fisik dalam melakukan kegiatan usahatani. Sedangkan pada lahan kering umur 
berpengaruh kurang signifikan dan negatif terhadap produksi padi. Dalam penelitian ini penambahan umur sebesar 1 persen akan mengurangi produksi padi sebesar 0,05 persen. Umur petani pada lahan kering rata-rata berumur 40,37 tahun yang dapat dikategorikan pada usia cukup tua. Sejalan dengan kemampuan produktifitas kinerja seseorang yang akan semakin meningkat pada umur tertentu, kemudian mengalami penurunan produktivitas kinerja petani jika mencapai pada titik umur tertentu. Umur mempengaruhi kemampuan fisik dalam melaksanakan kinerja seseorang sehingga semakin meningkatnya umur menyebabkan produktifitas kinerja seseorang semakin berkurang.

Tingkat pendidikan memiliki pengaruh yang tidak signifikan terhadap produksi padi lahan basah maupun lahan kering. Hal ini disebabkan karena tingkat pendidikan petani masih rendah, yaitu rata-rata berpendidikan Sekolah Dasar. Oleh karena itu, sesuai dengan kenyataan di lapangan menunjukkan bahwa tingkat pendidikan tinggi maupun rendah tidak mempengaruhi cara teknis budidaya padi yang dilakukan oleh petani. Usahatani padi secara umum di kabupaten Melawi masih tergolong mengunakan teknologi yang sederhana seperti pada umumnya, sudah menggunakan alat mesin pertanian misalnya dengan traktor, transplanter, Rice Milling Unit (RMU) dan pompa air yang mudah untuk dioperasikan. Penggunaan pupuk dan pestisida cukup menyesuaikan dengan dosis optimal pada pedoman umum usahatani padi sehingga mudah dilakukan dan diterapkan oleh petani pada tingkat pendidikan apapun.

\section{Analisis Faktor-Faktor yang Mempengaruhi Risiko Produksi Usahatani Padi Lahan Basah dan Lahan Kering.}

Untuk mengetahui pengaruh masing-masing faktor yang mempengaruhi risiko produksi padi berdasarkan nilai koefisien estimasi dari hasil uji $\mathrm{t}$ (individual test) dapat dilihat pada tabel 6 . Hasil uji t terhadap variabel independen yang digunakan dalam fungsi yang berpengaruh terhadap risiko produksi pada lahan basah yaitu hanya luas lahan berpengaruh kurang signifikan terhadap risiko produksi usahatani padi lahan basah sedangkan variabel independen lain yaitu benih, urea, NPK, herbisida, tenaga kerja keluarga, umur dan pendidikan tidak berpengaruh terhadap risiko produksi padi lahan basah. Sementara dalam fungsi risiko produksi lahan kering semua input variabel meliputi luas lahan, benih, herbisida, tenaga kerja keluarga, umur dan pendidikan tidak memberikan pengaruh terhadap risiko produksi 
Tabel 6. Hasil Estimasi Fungsi Risiko Produksi Usahatani Padi Lahan Basah dan Lahan Kering dengan model GARCH di Kabupaten Melawi Tahun 2015.

\begin{tabular}{|c|c|c|}
\hline \multirow[t]{2}{*}{ Variabel } & Lahan basah & Lahan kering \\
\hline & $\begin{array}{c}\text { Koefisien } \\
\text { estimasi }\end{array}$ & $\begin{array}{c}\text { Koefisien } \\
\text { estimasi }\end{array}$ \\
\hline (Constant) & $\begin{array}{c}0,633454 \\
(0,089125)\end{array}$ & $\begin{array}{c}-3,345022 \\
(-1,188885)\end{array}$ \\
\hline Luas Lahan & $\begin{array}{l}\text { 10,89516** } \\
(1,799948)\end{array}$ & $\begin{array}{c}1,402264 \\
(0,527528)\end{array}$ \\
\hline Benih & $\begin{array}{c}-0,073862 \\
(-0,260019)\end{array}$ & $\begin{array}{c}-0,039637 \\
(-0,559096)\end{array}$ \\
\hline UREA & $\begin{array}{c}0,005252 \\
(0,091727)\end{array}$ & $\begin{array}{l}- \\
-\end{array}$ \\
\hline NPK & $\begin{array}{c}0,006476 \\
(0,653985)\end{array}$ & $\begin{array}{l}- \\
-\end{array}$ \\
\hline Herbisida & $\begin{array}{c}0,000874 \\
(0,551230)\end{array}$ & $\begin{array}{c}0,000742 \\
(0,603665)\end{array}$ \\
\hline Tenaga Kerja Keluarga & $\begin{array}{c}-1,332182 \\
(-0,324189)\end{array}$ & $\begin{array}{c}0,152724 \\
(0,145811)\end{array}$ \\
\hline Umur & $\begin{array}{c}-0,092321 \\
(-0,789561)\end{array}$ & $\begin{array}{c}0,008588 \\
(0,202823)\end{array}$ \\
\hline Pendidikan & $\begin{array}{c}-0,194901 \\
(-0,413225)\end{array}$ & $\begin{array}{c}0,225941 \\
(1,310639)\end{array}$ \\
\hline R-squared & 0,960432 & 0,957904 \\
\hline Adjusted R squared & 0,955974 & 0,954444 \\
\hline F-Statistik & 219,7940 & 281,5830 \\
\hline$* * *, * *, *$, signifikan $\alpha=$ & & \\
\hline
\end{tabular}

Faktor-faktor produksi bisa dikategorikan sebagai faktor yang dapat meningkatkan risiko (risk inducing factors) dan faktor yang dapat mengurangi risiko (risk reducing factors). Dalam penelitian ini luas lahan berpengaruh kurang signifikan dan positif terhadap risiko produksi usahatani padi lahan basah sedangkan pada usahatani padi lahan kering tidak signifikan dan positif terhadap risiko produksi. Penambahan luas lahan sampai pada batas tertentu akan meningkatkan risiko produksi. Pada usahatani lahan basah menunjukkan luas lahan dapat merupakan faktor peningkat risiko atau risk inducing walaupun berpengaruh kurang signifikan. Penambahan luas lahan sebesar 1 persen akan menambah risiko produksi padi sebesar 10,89 persen. Penggunaan luas lahan sampai pada batas tertentu juga akan meningkatkan produksi padi. Akan tetapi pada batas luas tertentu juga akan meningkatkan risiko produksi karena semakin luas lahan usahatani, akan semakin sulit dalam mengelola lahan karena semakin banyak pemeliharaan tanaman yang dilakukan dengan luas lahan tersebut.

Dengan semakin luas lahan usahatani akan meningkatkan penggunaan input sarana produksi dalam usahatani tersebut, sedangkan petani dihadapkan pada kondisi kekurangan sarana produksi. Sedangkan usahatani padi lahan kering luas lahan bertanda positif menunjukan sebagai faktor penambah risiko atau risk inducing factors walaupun berpengaruh tidak signifikan. Usahatani secara 
sederhana jarang menggunakan input sarana produksi seperti pupuk dan herbisida kalaupun ada dengan dosis kecil sehingga tidak ada risiko terjadi karena penggunaan input

Benih padi pada lahan basah dan lahan kering bertanda negatif menunjukkan benih merupakan faktor pengurang risiko atau risk reducing factors, artinya peningkatan jumlah benih akan mengurangi risiko produksi walaupun berpengaruh tidak signifikan. Benih padi lahan basah yang digunakan petani adalah hasil dari pembenihan sendiri masih tergolong benih yang baik tidak berpengaruh pada risiko produksi padi lahan basah. Sedangkan benih padi lahan kering merupakan benih padi varietas lokal walaupun tidak berpengaruh pada peningkatan produksi padi akan tetapi benih padi lokal merupakan benih yang tahan terhadap hama penyakit dan kekeringan pada batas tertentu sehingga tidak berpengaruh pada risiko produksi.

Penggunaan pupuk urea dan NPK pada usahatani padi lahan basah bertanda positif sehingga menjadi faktor penambah risiko atau risk inducing factors, meskipun tidak berpengaruh signifikan terhadap risiko produksi. Dosis pupuk urea dan NPK yang digunakan dalam penelitian masih di bawah kebutuhan optimal penggunaan pupuk dalam usahatani padi sehingga tidak memberikan risiko akibat penggunaan input pupuk tersebut. Sedangkan pada usahatani padi lahan kering tidak menggunakan pupuk sehingga tidak ada risiko produksi yang ditimbulkan akibat penggunaan input tersebut.

Herbisida pada lahan basah dan lahan kering bertanda positif menunjukkan herbisida merupakan faktor penambah risiko atau risk inducing factors, artinya peningkatan jumlah herbisida akan meningkatkan risiko produksi walaupun berpengaruh tidak signifikan. Oleh karena penggunaan herbisida masih dibawah kebutuhan optimal dalam usahatani padi, maka penggunaan input tersebut tidak menimbulkan risiko produksi.

Karakteristik petani yang terdiri dari jumlah tenaga keluarga, pendidikan, dan umur berpengaruh tidak signifikan terhadap risiko produksi pada usahatani padi lahan basah dan lahan kering. Walaupun karakterisitik petani sebagai penambah risiko atau risk inducing factors dan pengurang risiko atau risk reducing factors tetapi tidak akan mempengaruhi peningkatan risiko produksi atau tidak berisiko. Hal tersebut menunjukan bahwa jumlah tenaga kerja sesuai dengan kebutuhan luas lahan usahatani yang tidak luas karena tenaga kerja digunakan untuk pemeliharaan tanaman padi sehingga tidak menimbulkan risiko produksi. Sementara umur petani tidak memberikan pengaruh pada risiko produksi karena kondisi umur petani lahan basah dan lahan kering masih dalam keadaan umur produktif dan berpengalaman dalam melakukan usahataninya sehingga tidak menimbulkan risiko produksi usaha tani padi. Sedangkan pendidikan tidak mempengaruhi risiko produksi karena tingkat pendidikan petani dalam penelitian ini masih sesuai dengan kondisi teknologi usahatani padi sederhana pada lahan basah dan lahan kering pada saat ini.

\section{B. Perbedaan Risiko Produksi Padi Lahan Basah dan Lahan Kering}

Standar deviasi atau simpangan baku adalah suatu estimasi probabilitas perbedaan produksi nyata dari produksi yang diharapkan. Menurut Shook (dalam Fahmi, 2014) standard deviasi merupakan ukuran tingkat variasi nilai probabilitas individual dari rata-rata distribusi. Semakin besar nilai standar deviasi maka semakin besar penyimpangan yang menyebabkan risiko semakin besar dan 
demikian juga sebaliknya semakin kecil nilai standar deviasi maka semakin kecil risiko dalam usahatani tersebut.

Analisis statistik untuk mengetahui perbedaan risiko usahatani lahan basah dan lahan kering adalah dengan menggunakan uji t-tes independent. Data perbandingan risiko produksi lahan basah dan lahan kering hasil analisis statistik standar deviasi adalah sebagai berikut:

Tabel 7. Perbandingan Risiko Produksi Usahatani Padi Lahan Basah dan Lahan Kering.

\begin{tabular}{lll}
\hline Uraian & Variance & Standar Deviasi \\
\hline Lahan Basah & 120,66 & 10,98 \\
Lahan Kering & 62,60 & 7,91 \\
\hline Uji beda Variance: & & \\
$\mathrm{t}$ hitung & $40,94 * * *$ & \\
$\mathrm{t}$ tabel $(\alpha 5 \%)$ & 1,99 & \\
\hline
\end{tabular}

Sumber : Analisis Data 2015.

Berdasarkan hasil analisis statistik variance dan standar deviasi menunjukkan nilai varian maupun standar deviasi lahan basah lebih besar dibandingkan dengan nilai variance dan standar deviasi lahan kering. Hasil uji ttest rumus polled variance terhadap risiko produksi padi lahan basah dan lahan kering menunjukkan nilai t hitung 40,94 lebih besar daripada nilai t tabel yaitu 1,99. Oleh karena dapat disimpulkan bahwa risiko produksi usahatani padi lahan basah dan lahan kering adalah berbeda. Berdasarkan perbedaan nilai variance dan standar deviasi lahan basah lebih besar dari lahan kering menunjukkan bahwa risiko produksi lahan basah lebih besar dibandingkan dengan risiko produksi lahan kering.

Membahas tentang risiko tidak terpisahkan dengan penerimaan hasil (return). Menurut Fahmi (2014) return merupakan penerimaan atau hasil yang diperoleh oleh perusahaan, individu, dan institusi dari hasil usaha infestasi yang dilakukannya. Produksi yang didapatkan petani merupakan suatu bentuk penerimaan atau hasil yang didapat dari usahatani pada lahannya. Produksi padi dalam penelitian juga menunjukkan bahwa produksi padi rata-rata lahan basah sebesar 30,26 Kuintal/ha lebih besar dari produksi rata-rata lahan kering sebesar 17,38 kuintal/hektar. Kondisi tersebut menunjukan bahwa semakin besar produksi yang didapat maka risiko yang dihadapi juga akan semakin besar. Sejalan dengan Fahmi (2014) penerimaan hasil yang lebih besar maka risiko akan tinggi pula demikian juga sebaliknya apabila penerimaan rendah maka risiko juga kecil atau kurang berisiko.

Risiko produksi lahan basah lebih besar dapat diakibatkan pada penggunaan input sarana produksi usahatani yang lebih kompleks jika dibandingkan dengan usahatani lahan kering. Pada usahatani padi lahan basah melakukan pengolahan tanah secara manual atau menggunakan alat mekanisasi pertanian (traktor), kemudian menggunakan pupuk yang optimal. Faktor ketersediaan air juga menjadi faktor risiko yang harus dipertimbangkan karena padi lahan basah harus tergantung dengan sumber air. Oleh karena penggunaan input dan metode yang begitu kompleks tentunya juga dihadapkan pada risiko sebagai konsekuensi dari penggunaan input saprodi dan metode tersebut. Usahatani lahan kering merupakan usahatani tanaman padi yang sederhana dan tidak banyak menggunakan input sarana produksi pertanian. Benih padi lahan kering yang digunakan merupakan 
benih padi lokal yang tahan terhadap hama dan penyakit serta kekeringan pada batas tertentu. Sehingga risiko akibat dari penggunaan input sarana produksi pada usahatani lahan kering lebih kecil. Dalam usahatani padi lahan kering juga menggunakan air untuk pertumbuhan tetapi tidak selalu digenangi seperti halnya pada lahan basah.

Pengaruh gangguan stokastik alam pada kegiatan produksi pertanian menjadi sumber utama risiko produksi (Fufa \& Hasan, 2005). Hal tersebut menunjukkan bahwa sumber-sumber risiko bisa berasal dari faktor eksternal seperti iklim dan cuaca. Dalam penelitian ini faktor eksternal yang menyebabkan risiko produksi lahan basah lebih tinggi adalah banjir dan kekeringan. Kondisi demikian disebabkan karena usahatani lahan basah berada pada lahan dataran rendah sehingga terjadi banjir akibat luapan air hujan, air sungai apalagi jika kondisi drainase yang buruk. Sedangkan usahatani lahan kering berada pada lahan yang tidak selalu digenangi air karena selalu berada pada lahan perbukitan yang agak lebih tinggi. Memasuki musim kemarau pada lahan sawah akan selalu rentan terhadap risiko kekeringan karena padi lahan sawah harus selalu digenangi air, sedangkan padi lahan kering yang tidak terbiasa digenangi air sehingga risiko lebih kecil. Usahatani padi lahan basah juga lebih rentan terhadap risiko serangan hama dan penyakit dikarenakan lingkungan padi di sawah yang tergenang menyebabkan kondisi yang lembab memudahkan untuk hama dan penyakit berkembang.

Walaupun risiko produksi usahatani padi lahan basah lebih tinggi masih layak untuk dikembangkan karena produksi padi yang didapatkan juga lebih tinggi. Oleh karena itu usaha ekstensifikasi dan intensifikasi harus dilakukan untuk meningkatkan produksi. Upaya perluasan cetak sawah baru perlu dilakukan untuk menambah luas areal sawah baru karena masih banyak lahan potensi sawah yang belum dimanfaatkan maksimal. Dukungan pemerintah sangat dibutuhkan dalam membangun cetak sawah baru beserta tersebut infrastruktur jaringan irigasi dan jalan usahataninya. Jumlah pupuk bersubisidi harus ditingkatkan disertai pengawasan dalam pendistribusian ke tingkat petani agar tidak terlambat dan jumlah yang diterima tidak berkurang.

Untuk mengatasi kekurangan air pada musim kemarau maka pembangunan embung dan bantuan sumur pompa diperlukan untuk persediaan air irigasi sawah petani. Jaringan irigasi tersier yang masih kurang dan merehab yang sudah ada karena selama ini pembangunan jaringan irigasi tidak disertai dengan perawatan jaringan tersebut.

Usahatani padi lahan kering mempunyai risiko produksi lebih kecil dengan produksi padi lebih rendah. Produksi padi yang rendah masih tetap diusahakan untuk memenuhi kebutuhan pangan petani sehari-hari. Sosial ekonomi masyarakat agraris sepenuhnya menggantungkan hidupnya pada pertanian padi. Usahatani padi lahan kering yang selalu dengan pola tanam lahan bergilir setiap tahunnya perlu diatur menjadi pola tanam lahan menetap untuk mengoptimalkan lahan. Pemupukan padi lahan kering perlu diberikan karena unsur hara dari bahan organik sisa pembakaran tanaman terbatas jumlahnya. Peran Penyuluh pertanian sangat diperlukan untuk memberikan penyuluhan budidaya pertanian padi yang baik terutama budidaya padi pola tanam menetap dan anjuran pemupukan padi lahan kering yang selama ini jarang dilakukan. 


\section{KESIMPULAN DAN SARAN \\ Kesimpulan}

Faktor-faktor yang mempengaruhi produksi usahatani padi lahan basah adalah luas lahan, benih, urea, herbisida, tenaga kerja keluarga, sedangkan, NPK, umur dan pendidikan tidak berpengaruh terhadap produksi padi sementara faktor yang mempengaruhi produksi usahatani padi lahan kering adalah luas lahan, herbisida, jumlah tenaga kerja keluarga dan umur, sedangkan benih dan pendidikan tidak mempengaruhi produksi padi.

Luas lahan berpengaruh kurang signifikan terhadap peningkatan risiko produksi pada usahatani padi lahan basah sedangkan faktor produksi lain tidak berpengaruh terhadap risiko produksi. Sementara semua faktor produksi tidak mempengaruhi risiko produksi usahatani padi lahan kering.

Terdapat perbedaan risiko antara usahatani lahan basah dan lahan kering dimana risiko produksi padi lahan basah lebih besar jika dibandingkan dengan risiko lahan kering.

\section{Saran}

Penelitian lanjutan perlu dilakukan untuk memaksimalkan fungsi lahan dengan intensifikasi lahan dalam rangka meningkatkan produktifitas padi pada lahan sawah dan lahan kering.

Fungsi luas lahan memberikan pengaruh yang sangat signifikan terhadap produksi padi dengan nilai estimasi fungsi yang sangat tinggi, oleh karena itu upaya perluasan areal lahan sawah oleh pemerintah perlu diberikan dengan program cetak sawah dan saprodi penunjangnya karena banyak potensi lahan sawah dengan kondisi medan dan vegetasi berat yang tidak bisa dibuka oleh petani karena keterbatasan biaya .

Produksi usahatani padi lahan basah lebih tinggi namun lebih berisiko untuk itu perlu upaya intensifikasi lahan dalam mengurangi risiko dan semakin meningkatkan produktifitas padi. Pemerintah perlu meningkatkan bantuan saprodi pupuk, pestisida dan alsintan karena petani masih kekurangan disertai pengawasan distribusi pupuk agar tepat waktu dengan kondisi baik sampai ke petani. Bantuan pemerintah berupa sarana jaringan irigasi dan pembangunan embung perlu ditingkatkan untuk menanggulangi risiko banjir dan kekeringan.

Usahatani padi lahan kering dengan produksi rendah tetap perlu ditingkatkan karena memiliki potensi lahan yang lebih luas dan merupakan usahatani masyarakat dalam rangka pemenuhan kebutuhan hidup sehari-hari. Bimbingan pemerintah secara khusus Penyuluh Pertanian Lapangan (PPL) sangat diperlukan dalam teknik budidaya padi dengan pola tanam menetap untuk mengoptimalkan lahan sehingga terjadi peningkatan luas lahan usahatani padi lahan kering.

\section{DAFTAR PUSTAKA}

Asche, F., \& Tveteras, R. (1999). Modeliing Production Risk With a Two-Step Procedure. Journal ofAgricultural and Resource Economics 24 (2) , 424439.

Debertin, D. L. (1986). Agricultural Production Economics. New York: Macmillan Publishing Company.

Fahmi, I. (2014). Pengantar Manajemen Keuangan. Bandung: Penerbit Alfabeta. 
Fufa, B., \& Hasan, R. M. (2005). Stochastic Technology and Crop Production Risk: The Case of Small-Scale Farmers in East Hararghe Zone of Oromiya Regional State in Ethiopia. Shared Growth In Africa Organized by ISSER/Cornell University/World Bank to be conducted from July 21-22, 2005 in Accra, Ghana (pp. 1-19). Ghana: ISSER/Cornell University/World Bank.

Ghozali, I. (2005). Aplikasi Analisis Multivariate dengan Program SPSS. Semarang: Badan Penerbit UNDIP.

Gujarati, D. N. (2006). Dasar-Dasar Ekonometrika Jilid II. Jakarta: Penerbit Erlangga.

Guttormsen, A. G., \& Roll, K. H. (2013). Production Risk in Subsistence Agriculture. The Journal of Agricultural Education and Extension , 1-13.

Hardjowigeno, S., \& Rayes, M. L. (2005). Tanah Sawah: Karakteristik, Kondisi, dan Permasalahan Tanah Sawah di Indonesia. Malang: Bayumedia Publishing.

Kanisius, A. A. (1990). Budidaya Tanaman Padi. Jakarta: Kanisius.

Koundori, P., \& Nauges, C. (2005). On Production Function Estimation With Selectivity and Risk Considerations. Journal Of Agricultural and Resource Economics 30 (3), 597-608.

Robison, L. J., \& Barry, P. J. (1987). The Competitive Firm's Response To Risk. New York: MacMillan Publishing Company.

Soekartawi. (1994). Teori Ekonomi Produksi dengan Pokok Bahasan Analisis Fungsi Produksi Cobb-Douglas. Jakarta: Penerbit Raja Grafindo Persada.

Soekartawi, Rusmadi, \& Darmaijati, E. (1993). Risiko dan Ketidakpastian dalam Agribisnis : Teori dan Aplikasi. Jakarta: Raja Grafindo Persada.

Sudarmanto, R. G. (2005). Analisis Regresi Linear Berganda dengan SPSS. Yogyakarta: Penerbit Graha Ilmu.

Sugiyono. (2009). Statistik Untuk Penelitian. Bandung: Penerbit Alfabeta Bandung.

Suratiyah, K. (2006). Ilmu Usahatani. Jakarta: Penebar Swadaya.

Tasman, A., \& Aima, H. (2014). Ekonomi Manajerial. Jakarta: PT Rajagrafindo Persada. 